$12-2014$

\title{
Specially Invited Opinions and Research Report of the International Water Law Project: Global Perspectives on the Entry into Force of the UN Watercourses Convention 2014: Part One
}

Gabriel Eckstein

Texas A\&M University School of Law, gabrieleckstein@law.tamu.edu

Salman M.A. Salman

Dinara Ziganshina

Kishor Uprety

Götz Reichert

Follow this and additional works at: https://scholarship.law.tamu.edu/facscholar

Part of the International Law Commons, and the Water Law Commons

\section{Recommended Citation}

Gabriel Eckstein, Salman M. Salman, Dinara Ziganshina, Kishor Uprety \& Götz Reichert, Specially Invited Opinions and Research Report of the International Water Law Project: Global Perspectives on the Entry into Force of the UN Watercourses Convention 2014: Part One, 16 Water Pol'y 1198 (Gabriel Eckstein eds., 2014).

Available at: https://scholarship.law.tamu.edu/facscholar/1179

This Article is brought to you for free and open access by Texas A\&M Law Scholarship. It has been accepted for inclusion in Faculty Scholarship by an authorized administrator of Texas A\&M Law Scholarship. For more information, please contact aretteen@law.tamu.edu. 


\title{
Specially invited opinions and research report of the International Water Law Project: global perspectives on the entry into force of the UN Watercourses Convention 2014: part one
}

Gabriel Eckstein ${ }^{1}$ (Editor)

E-mail: gabrieleckstein@law.tamu.edu

\begin{abstract}
From the Editor-in-Chief, Dr Jerome Delli Priscoli: This is a research report on opinions of prominent international water lawyers from each continent on the potential impacts of the 1997 UN Convention on Non-Navigational Uses of International Watercourses. It will be published in two successive editions of Water Policy.
\end{abstract}

Keywords: International water law; Watercourses Convention

\section{Introduction to the series}

The following compilation is reproduced and adapted from a series of essays that appeared in the blog of the International Water Law Project (www.internationalwaterlaw.org). The series was solicited in preparation for the coming into force of the 1997 UN Convention on the Non-Navigational Uses of International Watercourses. The Convention had been pending for 17 years since its adoption by the United Nations General Assembly (UNGA) in 1997. On 19 May 2014, Vietnam became the 35th party to the treaty, bringing the total number of State Parties to 35, the minimum number of ratifications needed to bring that Convention into force.

In anticipation of this long-awaited occasion, during the summer of 2014, the International Water Law Project hosted a series of essays on its blog (www.internationalwaterlaw.org/blog/) from some of the most knowledgeable scholars and practitioners worldwide. The series provided unique

\footnotetext{
${ }^{1}$ Professor Eckstein is a member of the law faculty at Texas A\&M University, creator and director of the International Water Law Project, and editor of the International Water Law Project Blog.
}

doi: $10.2166 /$ wp. 2014.008

C) IWA Publishing 2014 
perspectives and information on the implications of the Convention for international water law and the global management of transboundary watercourses. The outcome was a fantastic, provocative, and timely compilation that offered readers both an introduction and unique insight into the Convention. It also offered readers the opportunity to participate in the discussion and offer their own perspectives and opinions by submitting comments on the various essays. While the essays have been included in the following compilation, the readers' comments can be found on the International Water Law Project Blog.

The International Water Law Project is itself a unique institution. Existing solely on the Internet, the website is one of the premier resources and clearing houses for information on international water law and policy. Its purpose is to educate and provide relevant resources to researchers and the public, and to facilitate cooperation over the world's freshwater resources.

\section{UN Convention finally in force}

On 19 May 2014, Vietnam became the 35th party to the 1997 UN Convention on the Law of the NonNavigational Uses of International Watercourses. As a result, on 17 August 2014, 90 days after that 35th ratification was deposited, the Convention came into force.

Long in coming, the Convention's success was never guaranteed. Adopted by the UN General Assembly (UNGA) in 1997, the Convention appeared set for ratification as 103 of the UN's Member States voted in favor of it. Only three countries voted against - Burundi, China, and Turkey - while 27 nations abstained and 33 were absent from the vote. That vote, however, masked long-standing disagreements over how transboundary freshwater resources should be allocated and managed. In particular, upper and lower riparians disagreed over the primacy of the Convention's cornerstone principles of equitable and reasonable use - favored by most upper riparians - and the doctrine of no significant harm - preferred by most lower riparians (Eckstein, 2002).

Lackluster support in the years following the Convention's inception suggested to some that the treaty was doomed to failure. More recently, though, the rate of ratifications more than doubled (18 in the first 12 years in comparison with 17 over the past 5 years). While that resurgence may have been due, in part, to the efforts of the World Wildlife Fund (which, in around 2009, added ratification of the Convention to its advocacy agenda), it also suggests a broadening recognition that nations have an obligation to cooperate over transboundary freshwater resources. Maybe it is the threat of climate change, or concerns over dwindling domestic water resources, but the fact that states are willing to bind themselves to the procedural and substantive norms of the Convention is a promising sign, especially since the transboundary character of freshwater resources globally represents the norm rather than the exception.

Sixty percent of all fresh water on Earth flows through basins shared by at least two countries; 21 countries lie entirely within international basins; 13 basins worldwide are shared between five and eight riparian nations; five basins (the Congo, Niger, Nile, Rhine, and Zambezi) are shared between nine and 11 countries; one river - the Danube - flows through the territory of 17 nations (UNEP, 2002). There are 276 watercourses traversing the boundaries of an estimated 145 countries, while nearly 450 transboundary aquifers and aquifer bodies have been identified crossing nearly every continental country (Eckstein \& Sindico, 2014). Hence, a global framework agreement guiding the management and governance of shared freshwater resources is both a logical achievement and a 
significant landmark in the evolution of international water law and the international community's efforts to better and peacefully manage transboundary freshwater resources.

Entry into force of the Convention, however, is not the last word on the matter. In fact, this milestone raises as many new questions as existed leading to its implementation. For example, what does the geographic distribution of member states indicate for the global success of the treaty? Of the 35 ratifications, the vast majority are from either Europe (16) or Africa (12); only two ratifying parties are found in Asia, and none come from the American hemisphere; five others are from the non-African Middle East region, albeit a total of eight nations from the so-called MENA region (Middle East and North Africa) are now State Parties to the Convention (see Figure 1). At the very least, this distribution suggests a certain geographic bias toward (and against) the Convention. In terms of upper and lower riparians, the picture is less clear. Of the 35 State Parties, five are mostly upper riparians, 10 are mostly lower riparians, 12 have mixed upper and lower riparian characteristics, and eight have no upper or lower riparian attributes, as outlined in Table 1.

Notwithstanding the geographic distribution, other questions arise. What will implementation of the Convention mean in practice? How will nations implement its mandates within their borders and in relation to riparian neighbors? Why have nations in the Americas and Asia eschewed ratification? What does the entry into force of the Convention mean for the United Nations Economic Commission for Europe (UNECE) Convention on the Protection and Use of Transboundary Watercourses and International Lakes (1992), which is already in force in much of Europe and, on 6 February 2013, opened its membership to the rest of the world? And, what will the Convention's implementation mean for existing regional and local transboundary freshwater agreements?

The following essays offer various and divergent perspectives from around the world about the UN Watercourses Convention (UNWC). While they do not answer all of these questions, they provide

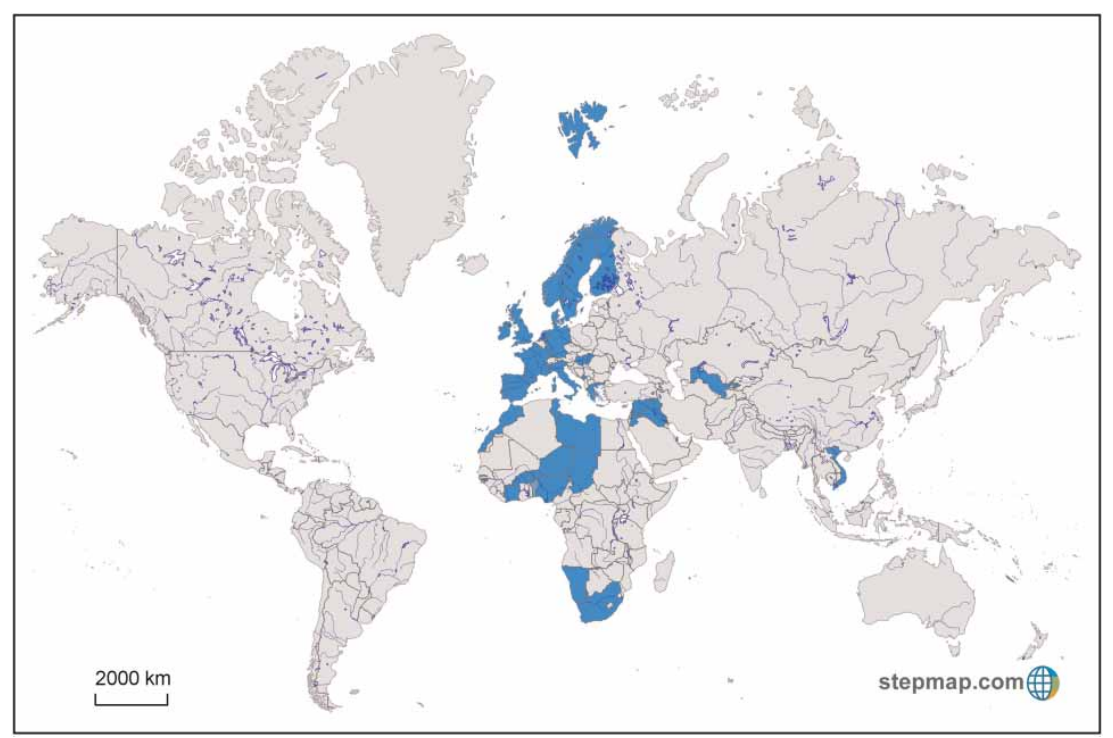

Fig. 1. Map of State Parties to the UN Watercourses Convention. 
Table 1. State Parties to the UN Watercourses Convention.

\begin{tabular}{|c|c|c|c|c|}
\hline Country & $\begin{array}{l}\text { Vote at UNGA } \\
\text { (1997) }\end{array}$ & $\begin{array}{l}\text { Riparian } \\
\text { characteristic }\end{array}$ & $\begin{array}{l}\text { Economic income } \\
\text { level* }\end{array}$ & Geographic region* \\
\hline Benin & Absent & Upper/lower & Low & Sub-Saharan Africa \\
\hline Burkina Faso & For & Mostly upper & Low & Sub-Saharan Africa \\
\hline Chad & Not recorded & Mostly upper & Low & Sub-Saharan Africa \\
\hline Côte d'Ivoire & For & Mostly lower & Low-middle & Sub-Saharan Africa \\
\hline Denmark & For & Neither & High & Western Europe \\
\hline Finland & For & Neither & High & Western Europe \\
\hline France & Abstain & Upper/lower & High & Western Europe \\
\hline Germany & For & Upper/lower & High & Western Europe \\
\hline Greece & For & Upper/lower & High & Western Europe \\
\hline Guinea-Bissau & Not recorded & Lower & Low & Sub-Saharan Africa \\
\hline Hungary & For & Upper/lower & Upper-middle & Eastern Europe and Central Asia \\
\hline Iraq & Not recorded & Lower & Upper-middle & Middle East and North Africa \\
\hline Ireland & For & Neither & High & Western Europe \\
\hline Italy & For & Neither & High & Western Europe \\
\hline Jordan & For & Neither & Upper-middle & Middle East and North Africa \\
\hline Lebanon & Absent & Upper & Upper-middle & Middle East and North Africa \\
\hline Libya & For & Neither & Upper-middle & Middle East and North Africa \\
\hline Luxembourg & For & Upper/lower & High & Western Europe \\
\hline Montenegro & Not applicable & Lower & Upper-middle & Eastern Europe and Central Asia \\
\hline Morocco & For & Neither & Lower-middle & Middle East and North Africa \\
\hline Namibia & For & Upper/lower & Upper-middle & Sub-Saharan Africa \\
\hline Netherlands & For & Mostly lower & High & Western Europe \\
\hline Niger & Absent & Upper/lower & Low & Sub-Saharan Africa \\
\hline Nigeria & Absent & Mostly lower & Lower-middle & Sub-Saharan Africa \\
\hline Norway & For & Upper/lower & High & Western Europe \\
\hline Portugal & For & Mostly lower & High & Western Europe \\
\hline Qatar & For & Neither & High & Middle East and North Africa \\
\hline South Africa & For & Mostly upper & Upper-middle & Sub-Saharan Africa \\
\hline Spain & Abstain & Upper & High & Western Europe \\
\hline Sweden & For & Upper/lower & High & Western Europe \\
\hline Syria & For & Upper/lower & Lower-middle & Middle East and North Africa \\
\hline Tunisia & For & Mostly lower & Upper-middle & Middle East and North Africa \\
\hline $\begin{array}{l}\text { United } \\
\text { Kingdom }\end{array}$ & For & Neither & High & Western Europe \\
\hline Uzbekistan & Abstain & Upper/lower & Lower-middle & Eastern Europe and Central Asia \\
\hline Vietnam & For & Mostly lower & Low & East Asia and Pacific Islands \\
\hline
\end{tabular}

*Economic income level and geographic region categories, except the Western Europe geographic region category, are based on classifications established by the World Bank. The Western Europe geographic region category was created by this author. The chart is adapted from Eckstein (2002).

Note: Paraguay, Venezuela, and Yemen have signed the Convention, but have not yet ratified it.

informative, and occasionally provocative, assessments and interpretations that further the conversation about the management of the world's shared water resources. The essays appear below in the order they appeared on the International Water Law Project Blog. 


\section{Dr Stephen McCaffrey ${ }^{2}$ on the entry into force of the 1997 Watercourses Convention}

With the 35th ratification by Vietnam on 19 May 2014, the 1997 Convention on the Law of the NonNavigational Uses of International Watercourses entered into force on 17 August 2014, 90 days after that ratification as provided by Article 36(1) of the Convention. While the pace of ratifications has been rather slow, after an initial burst by Middle Eastern states, it has picked up of late. The Convention's entry into force is no doubt a landmark event for international water law, but it also augurs well for the protection, use, and management of international freshwater resources according to generally accepted principles. Despite the importance of the Convention's entry into force, however, one should not lose sight of its significance as a reflection of basic principles of customary international law on the subject.

It is well known that the Convention was negotiated at the United Nations Headquarters in 1996 and 1997 on the basis of a set of draft articles prepared by the International Law Commission over a 20-year period (1974-1994). The Commission had been requested by the General Assembly in 1970 to study the topic with a view to its progressive development and codification. 'Codification' in this context refers to the more precise formulation of rules of customary international law. The Commission's draft articles were adopted by the negotiating governments with only minor - albeit in certain cases important - changes. The result is a treaty that would be expected to codify the most fundamental principles of the law of international watercourses. Those principles are generally believed to be equitable and reasonable utilization, prevention of significant harm, and prior notification of planned measures. They are expressed in specific provisions of the Convention, but a number of other provisions are supportive of or ancillary to them - such as the general obligation to cooperate, the obligation to exchange data and information on a regular basis, and the obligation to protect and preserve aquatic ecosystems. To the extent that the 1997 Convention represents such a codification, the rules reflected in it would be binding on all states as customary international law whether or not the Convention was in force for a particular state.

Rather remarkably, almost immediately after the Convention was concluded, the International Court of Justice began drawing heavily upon it in its judgments. Thus in the Gabčíkovo-Nagymaros Project case (Hungary/Slovakia) (ICJ, 1997), decided 4 months after the Convention was concluded, the Court quoted from the Convention as support for principles it articulated, and relied on what is perhaps the Convention's most basic principle, equitable and reasonable utilization, calling it a 'basic right' of all states sharing international watercourses. The same principle figured prominently in the case concerning Pulp Mills on the River Uruguay (Argentina v. Uruguay) (ICJ, 2010).

An aspect of the Convention's scope that is sometimes not fully appreciated is that it covers both surface water and related groundwater. This is due to the way the term 'watercourse' is defined, to mean 'a system of surface waters and groundwaters constituting by virtue of their physical relationship a unitary whole ...' (Article 2(a)). Since most of Earth's groundwater interacts with surface water, this coverage is quite broad. And importantly so, since some $97 \%$ of the fresh water available for human use is underground. Thus, the Convention's provisions would apply to shared aquifers that have some connection with surface water as well as aquifers that are not themselves shared but which have a hydraulic connection with shared surface water.

\footnotetext{
${ }^{2}$ Dr McCaffrey is the distinguished professor of law at the University of the Pacific McGeorge School of Law and former special rapporteur of the UN International Law Commission for the draft articles on the law of the non-navigational uses of international watercourses. Dr McCaffrey can be contacted at smccaffrey@pacific.edu.
} 
A final point raised by the entry into force of the 1997 Watercourses Convention concerns the relationship of that treaty to the UNECE Convention on the Protection and Use of Transboundary Watercourses and International Lakes (1992). The latter agreement was originally envisaged and designed as a regional instrument covering states within the ECE. This is reflected in the rather low number of parties required for its entry into force (16, under Article 26(1)) and by its emphasis on avoidance of transboundary impact, defined as 'any significant adverse effect on the environment' (Article 1(2)), an issue of particular concern in the generally well-watered and developed region. By virtue of an amendment to the ECE Convention that entered into force on 6 February 2013, the agreement is open to accession by states outside the UNECE region. Thus, with the entry into force of the 1997 UN Convention, there are two treaties on shared freshwater resources that are open to participation by all states. This raises the question whether the two are compatible.

The answer, in my judgment, is yes. The two treaties have essentially the same object and purpose cooperative use, management, and protection of shared freshwater resources - even though they go about accomplishing them somewhat differently. The 1992 Convention contains far more detailed provisions on avoidance of transboundary impact, and protection of international watercourses from pollution, but these are complementary to the corresponding, more general, provisions of the 1997 Convention. Likewise, the emphasis of the 1997 Convention on equitable and reasonable utilization complements the 1992 Convention, which covers the principle concisely in the context of activities that cause or may cause transboundary impact (Article 2(2)(c)). The fact that one state with significant international watercourses, Uzbekistan, has already ratified both treaties suggests that governments, too, see a synergy between them.

In conclusion, the entry into force of the 1997 Watercourses Convention is a signal event in the development of international water law. The fact that it took a number of years to achieve this status should not be a concern. The Convention expresses basic principles of customary international law in the field. In any event, many states who might otherwise have joined it already have their freshwater relations covered by specific agreements, and experience has shown that bringing general agreements like this into force can take time. But now that the Convention has achieved the required number of ratifications to bring it into force, parties will have a constitution for their water relations, something that may encourage non-parties to join, as well.

\section{Dr Salman M.A. Salman ${ }^{3}$ on entry into force of the UNWC - where are the Nile Basin countries?}

The year 1997 was a defining point in history for both the Nile Basin countries and the UNWC. At the beginning of that year, informal contacts facilitated by the World Bank and United Nations Development Programme (UNDP) resulted in a preliminary agreement to establish, for the first time, a forum inclusive of all the Nile riparian countries (Figure 2). In May of the same year, the UNGA adopted the UNWC by a large majority, paving the way for its entry into force and effect. Unfortunately, that point in history also turned out to be a departure point as none of the Nile riparian countries became a party to the UN Convention. This essay addresses the reasons behind this sad fact.

\footnotetext{
${ }^{3}$ Dr Salman is an academic researcher and consultant on water law and policy, and editor-in-chief of Brill Research Perspectives, International Water Law. Until 2009, Dr Salman served as Lead Council and Water Law Adviser for the World Bank. He can be reached at salmanmasalman@gmail.com.
} 


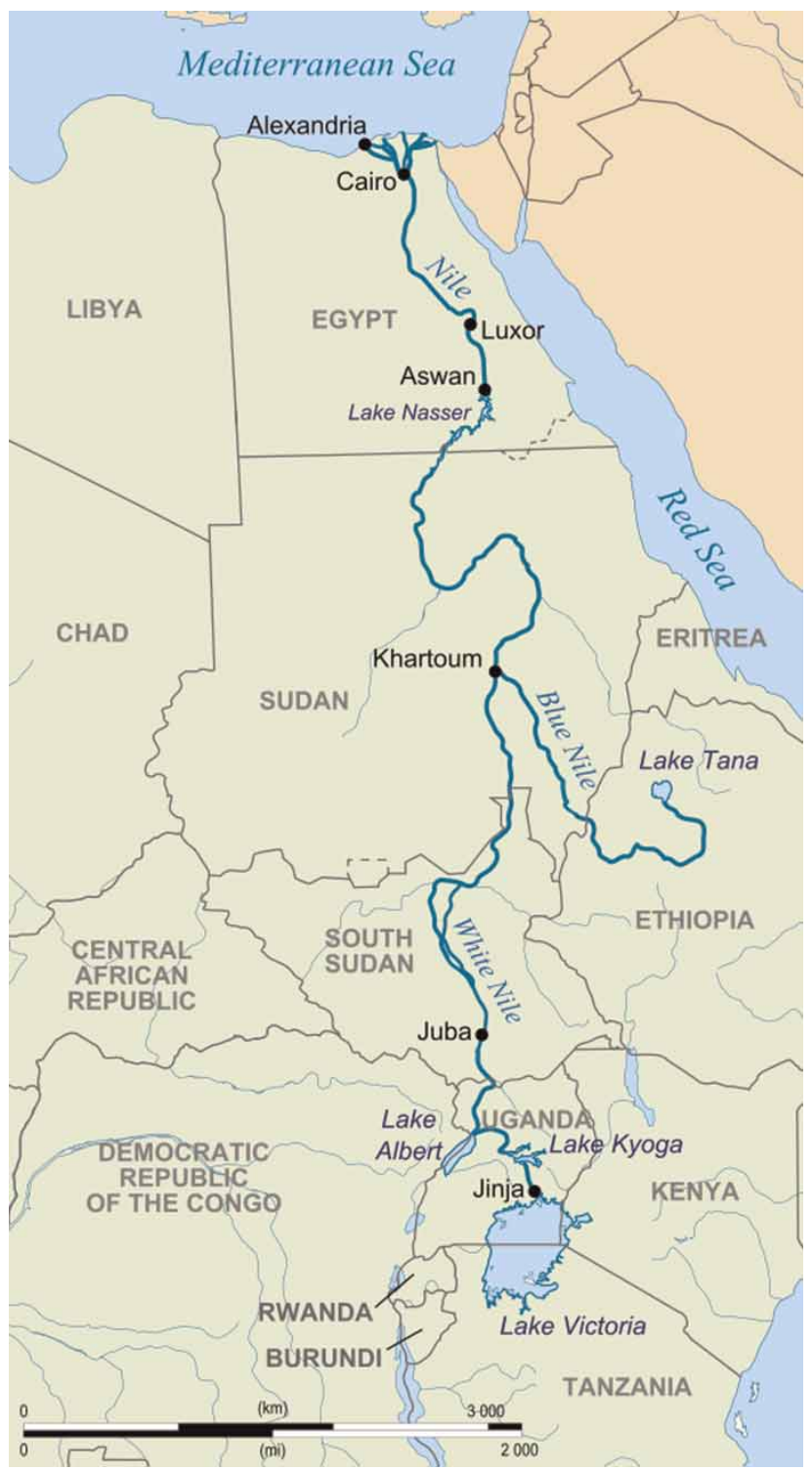

Fig. 2. The Nile River Basin. Source: Wikipedia.

Pursuant to the 1997 contacts and the subsequent facilitation by the World Bank and UNDP, the Nile Basin Initiative (NBI) was formally established by the Nile Basin states at the meeting of their Ministers of Water Resources in Dar-es-Salaam, Tanzania, on 22 February 1999. The agreed minutes of the meeting, signed by the ministers in attendance, included the overall framework for the NBI and its institutional structure and functions. The NBI is guided by a shared vision 'to achieve sustainable socio-economic development through equitable utilization of, and benefit from, the common Nile Basin water resources' (NBI website: http://nilebasin.org/index.php/about-us/nile-basin-initiative). The main objective of the NBI was to negotiate 
and conclude a cooperative framework agreement that would incorporate the principles, structures, and institutions of the NBI, and that would be inclusive of all Nile riparians.

Work on the Nile Basin Cooperative Framework Agreement (CFA) commenced immediately after the NBI was formally established in 1999 (Agreement On the Nile River Basin Cooperative Framework, 2010), and continued for more than 10 years. However, the process ran into major difficulties as a result of the resurfacing and hardening of the respective positions of the riparians. Egypt and Sudan, the two lower riparians, insisted on the validity and binding obligations on the upper riparians of the treaties concluded in 1902 (Treaty between His Majesty's Government in the United Kingdom and Ethiopia, and between the United Kingdom, Italy, and Ethiopia, relative to the frontiers between the Sudan, Ethiopia, and Eritrea, 1902) and 1929 (Exchange of notes between His Majesty's Government in the United Kingdom and the Egyptian Government in regard to the use of the waters of the River Nile for irrigation purposes, 1929), which the upstream riparians have persistently and completely rejected. Those two treaties purportedly give Egypt and Sudan veto power over any project in any of the upper riparian states. Moreover, Egypt and Sudan insisted on their claims to their acquired rights and uses of the Nile waters under the 1959 Nile Waters Agreement (Agreement (with Annexes) between the United Arab Republic and the Republic of Sudan for the full utilization of the Nile waters, 1959), which the upper riparians also squarely rejected since it left no Nile waters for them. Those differences persisted and could not be resolved at the negotiations level. They were eventually taken to three ministerial meetings in Kinshasa, Alexandria, and Sharm El-Sheikh in 2009 and 2010. However, these meetings failed to resolve these issues, and no agreement on the final draft CFA was reached.

On 14 May 2010, four of the Nile riparians (Ethiopia, Tanzania, Uganda, and Rwanda) signed the CFA. They were joined 5 days later by Kenya, and then by Burundi on 28 February 2011. Although the Democratic Republic of Congo and the newly independent nation of South Sudan both indicated their support for the CFA, neither has signed nor become a party to the instrument. Ethiopia eventually ratified the CFA in June 2013, but no other signatory state followed. The CFA needs six ratifications to enter into force and effect.

Egypt and Sudan vehemently oppose the signed version of the CFA, because it does not incorporate their concerns under the 1902, 1929, and 1959 treaties. As a result, the division of the Nile Basin countries into lower and upper riparians has sharpened and escalated.

Similar to the UNWC, the CFA lays down basic principles for the protection, use, conservation, and development of the Nile Basin. These include cooperation between the states of the Nile River Basin on the basis of sovereign equality, territorial integrity, mutual benefit and good faith, sustainable development, equitable and reasonable utilization, and prevention of significant harm, as well as procedures for settlement of disputes. Cooperation is clearly and unequivocally the defining and common theme of the two instruments.

Yet despite the similarities between the two instruments, the positions of the Nile riparian countries toward the UN Convention vary significantly. When the Convention came before the UNGA, Kenya and Sudan voted in favor, while Burundi joined Turkey and China in their negative vote. Egypt, Ethiopia, Tanzania, and Rwanda abstained, each for different reasons, while Uganda, the Democratic Republic of Congo, and Eritrea did not participate in the vote. As of today, none of the Nile riparian countries have signed or ratified the UNWC, not even Kenya or Sudan, which voted for the Convention. In contrast, Ethiopia, Kenya, Uganda, Tanzania, Burundi, and Rwanda signed the CFA, and Ethiopia ratified it.

This may seem baffling. Why would the six countries that signed the CFA refuse to join the UNWC, given that the CFA is derived from and largely based on the Convention? The answer rests with the controversies surrounding the Nile treaties referred to above. The six upper riparians that signed the CFA do not want to be parties to a Convention that includes clear and detailed obligations for the notification of other riparians of 
planned measures and projects in their territories that may affect the Nile. They are concerned that such notification obligations would be construed by Egypt and Sudan as recognition of the 1902 and 1929 treaties that give Egypt and Sudan veto power over upstream activities. Indeed, this is the main reason that the CFA does not include provisions on notification, only on exchange of data and information.

On the other hand, Egypt and Sudan cling strongly to their historical rights and uses, and both believe that the UNWC tilts toward equitable and reasonable utilization at the expense of the obligation not to cause significant harm. As lower riparians with claimed historical rights over the Nile waters, their cardinal principle is the obligation not to cause significant harm. They read the decision of the International Court of Justice in the Gabčikovo-Nagymaros Project case (Hungary/Slovakia) (ICJ, 1997) as heightening and underscoring their concern that the Convention may have subordinated this obligation to the principle of equitable utilization. For this reason, they would not accede to the Convention.

Thus, for the 11 Nile riparian countries, accession to the UNWC is deeply intertwined with the controversies regarding the so-called 'colonial Nile treaties'. In particular, Egypt and Sudan's position reflects a major failure by both countries to view cooperation, equitable and reasonable utilization, and the obligation not to cause significant harm, as all closely related and interwoven, and not as separable elements of international water law. Thus, any attempt to resolve the pending issues under the CFA, the Grand Ethiopian Renaissance Dam, or accession to the UNWC will prove futile until Egypt and Sudan recognize that these treaties are outdated and non-functional, because they have simply been totally ignored by the other riparians, both in theory and in practice.

Indeed, it is time for both Egypt and Sudan to remove these 'colonial treaties' out of the flow of Nile negotiations and to join both the CFA and the Convention. Such a bold, albeit realistic, step would generate a new and genuine spirit of cooperation among the Nile states, and reignite the world community's goodwill for the region. It would also pave the way for an equitable sharing of the benefits of the common Nile waters by the 11 riparians, without real harm to either Egypt or Sudan.

In turn, these events would no doubt end the current sad state of affairs of conflict and disputes over the Nile, and help lift the 300 million inhabitants of the Nile from their ever-increasing misery, poverty, and underdevelopment. After all, the vision of the NBI itself, which Egypt and Sudan subscribed to in 1999, is to achieve sustainable socio-economic development through equitable utilization of, and benefit from, the common Nile Basin water resources. Indeed, this is what both the CFA and the Convention are about.

\section{Dr Dinara Ziganshina ${ }^{4}$ on the UNWC in Central Asia - the current state and future outlook}

\subsection{The role and relevance of the UN Convention in Central Asia}

Managing the impacts of climate change and demographic growth, as well as reconciling different demands on water for drinking needs and sanitation, ecosystems, agriculture, food production, industry, and energy are major water security challenges in the Aral Sea basin shared by Afghanistan, Kazakhstan, the Kyrgyz Republic, Tajikistan, Turkmenistan, and Uzbekistan (see Figure 3). These challenges require a holistic, mutually beneficial, and cooperative solution that is agreeable to all parties involved. A 2011 regional assessment on the role and relevance of the 1997 UNWC to the Aral

\footnotetext{
${ }^{4}$ Dr Ziganshina is based in Tashkent, Uzbekistan, where she serves as deputy director of the Scientific Information Center of Interstate Commission for Water Coordination in Central Asia. She can be reached at dinara.ziganshina@gmail.com.
} 


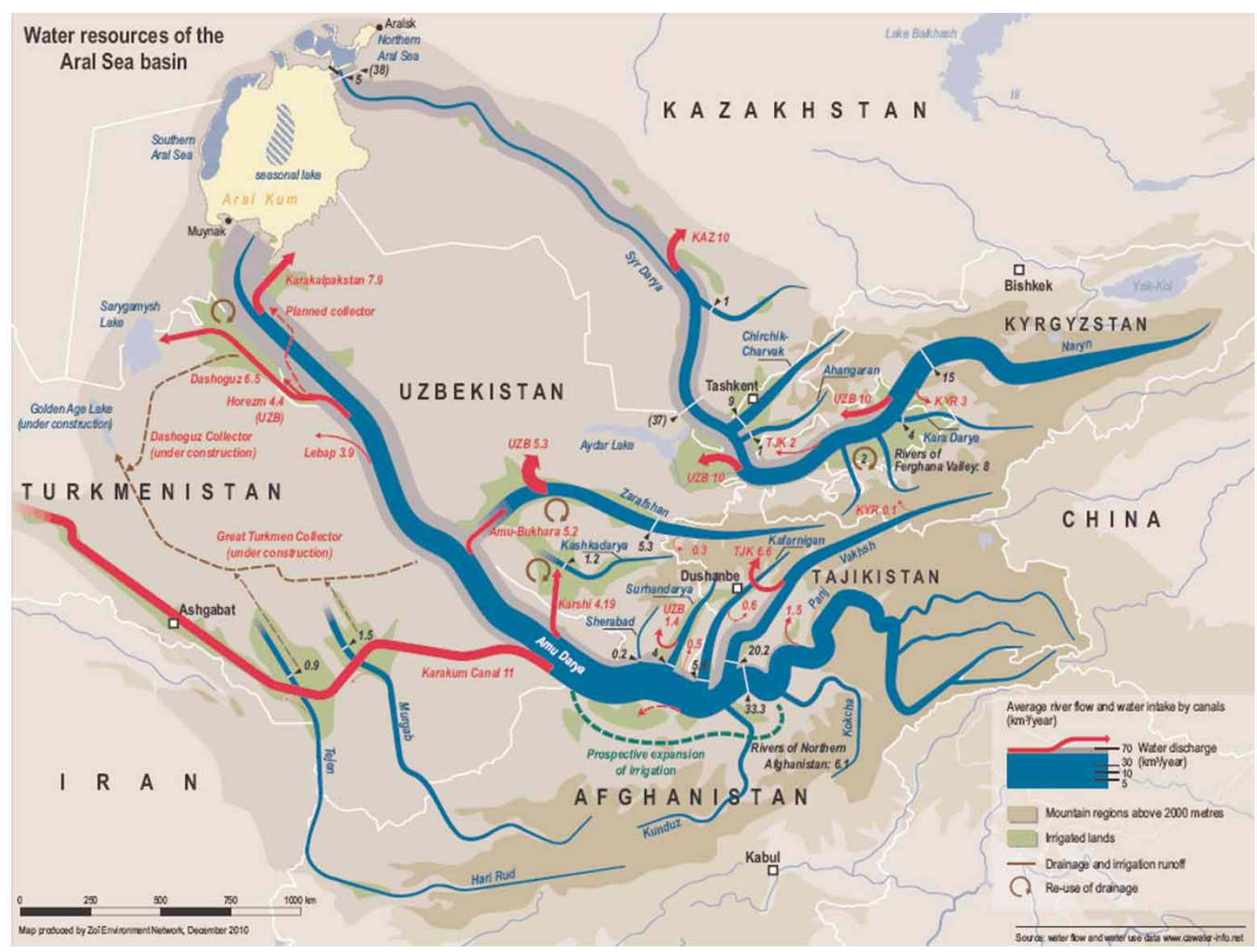

Fig. 3. Water resources of the Aral Sea Basin. Source: Amu Darya Basin Network: http://amudaryabasin.net/.

Sea basin countries found that this global instrument could improve the legal framework for transboundary water cooperation in the basin, and assist countries in building and maintaining effective and peaceful management systems for their shared water resources (Ziganshina, 2011).

Although there are plenty of legal instruments at the bilateral, sub-basin, and basin levels governing the use and protection of shared watercourses in Central Asia, these agreements are in dire need of improvement as they fail to incorporate key principles of international water law and best management practices. In this context, the UN Convention could play a supplementary role to the existing regimes, and serve as a resource to help interpret the region's bilateral treaties and arrangements. While the norms of the UN Convention are mostly couched in broad terms, to be applied to a range of different river basins, some of its provisions are still more precise and specific than the norms of sub-regional agreements in the Aral Sea basin. The rule of equitable and reasonable use and the notification procedure on planned measures, which the sub-regional agreements seem to subsume under 'joint management' and 'joint consideration' provisions, are the most notable examples.

In addition, the UN Convention could serve as a common platform for Central Asian countries to negotiate future accords, since it does not preclude or dismiss the need for local and regional watercourse agreements. 
Existing legal arrangements in the basin were not designed to accommodate changing circumstances, nor can they be easily amended. As a result, many of these treaties have become stagnant and have lost their value.

Most prominently, by joining the UN Convention, Central Asian countries could benefit not only from its individual provisions, but also from the entire text of the Convention, which was carefully crafted to provide a system of interacting and mutually supporting rules and procedures. Of particular relevance is the Convention's contribution to the peaceful management of controversies as manifested in its sound procedural system and range of dispute-settlement mechanisms, including an impartial factfinding commission.

\subsection{Perspectives for the UN Convention in the region}

Despite the UN Convention's value and relevance, Uzbekistan remains the only country from the region to have acceded to it. During the Convention's adoption by the UNGA in 1997, none of the Central Asian nations voted against it. While Kazakhstan voted in favor and Uzbekistan abstained from the vote, the Kyrgyz Republic, Tajikistan, and Turkmenistan were absent from the voting process. The example of Uzbekistan, which abstained from voting but eventually acceded to the Convention, demonstrates the possibility that countries can change their position. One can speculate on the reasons for Uzbekistan's change, which may be grounded in political considerations, increased environmental and social concerns related to transboundary waters, or improved legal understanding of the benefits from the Convention for the peaceful use of the resource. It is also possible that the country intended to express its position to the international community by cementing its adherence to international water law. In this context, what are the chances that other countries in the region will join the Convention?

Kazakhstan, which voted in favor of the Convention, is the most likely candidate. This would be a logical, and not very demanding, step for the country, since it has already committed to all water-related UNECE Conventions, which impose even stricter obligations. The Espoo Convention on Environmental Impact Assessment in a Transboundary Context (1991), for example, sets forth detailed provisions on notification procedures for planned measures, while the 1992 UNECE Watercourses Convention stipulates stringent requirements for preventing and controlling transboundary harm, environmental protection, and establishing joint bodies.

Turkmenistan is another downstream country that has considered joining the UN Convention, after recently acceding to the UNECE Watercourses Convention. An official representative of that country stated at a 2011 international water conference in Tashkent that preparatory procedures to join the Convention were under way.

The chance in the short term that the two upstream countries of Kyrgyzstan and Tajikistan might join the UN Convention, however, is not very high. In the early 2000s, the Ministry of Foreign Affairs of the Kyrgyz Republic found it inadvisable for the country to accede to the Convention (Ziganshina, 2011), although Kyrgyzstan acceded to the Espoo Convention in 2001. Since then, there has been no evidence of a changed attitude toward the Convention. The head of the Kyrgyz delegation to the 2011 Tashkent international water conference largely supported this proposition and added that his country may consider joining the 1999 Protocol on Water and Health under the UNECE Watercourses Convention (Protocol on Water and Health to the 1992 Convention on the Protection and Use of Transboundary Watercourses and International Lakes, 1999) as a first step. At the same time, he added that Kyrgyzstan would be more willing to sign up to the UN Convention than the UNECE Watercourses Convention as, in his opinion, it was more relevant to the issues facing the Central Asian region (Ziganshina, 2011). 
Similarly, Tajikistan is reluctant to accede to the Convention despite the fact that the President of Tajikistan has highlighted the key role of international agreements in addressing water-related problems in the region. For instance, in his address at the first Asian Pacific Water Summit, Emomali Rahmon stated, 'Elaboration and adoption of International Water Convention could be one of the important steps in a unification of efforts which would determine universal principles of water policy taking into account ensuring the interests of all consumers'. Nevertheless, Tajikistan's existing legal commitments could set the pace for it to join the Convention. For example, under the Commonwealth of Independent States Agreement on Transboundary Waters (1998), Tajikistan agreed to take into account the provisions of the 1966 Helsinki Rules, on which the UN Convention is largely based, and those of the UNECE Watercourses Convention. In addition, on 17 February 2004, Tajikistan promulgated Decree 1287 on Accession to the Espoo Convention, however, the Depositary of the Convention has not yet received the ratification documents. If Tajikistan completes the ratification process for the Espoo Convention, it will be a party to another instrument largely aligned with the procedural norms of international water law.

\subsection{The way forward}

The unwillingness of the two upstream countries to join the UN Convention does not appear to be based on their rejection of its normative prescriptions, but rather is due to a misunderstanding of its provisions. The UN Convention has been criticized by some nations as giving preferential treatment to the interests of wealthy and powerful states, ignoring the situation in water-stressed countries, leaving individual states too much discretion to interpret its provisions for their own benefit, and being vague and imprecise in defining the rights and obligations imposed on riparian countries.

A careful analysis of the UN Convention and the broader international legal environment in which it sits dispels some of these apprehensions. The Convention imposes identical obligations on all watercourse states, irrespective of their location on an international watercourse. Moreover, concerns related to vagueness and lack of precision must be tempered by the understanding of the framework and residual character of the Convention. Lastly, the Convention must be viewed as a system of substantive and procedural obligations that establish a regime resulting from all of its provisions considered collectively.

The UN Convention has much to offer the countries of the Aral Sea basin in addressing their transboundary water problems. But to secure its benefits, the countries in the region must take an informed decision to join the Convention and implement its provisions. This means that remaining misconceptions about the Convention must be clarified, and care must be taken not to create additional confusion. This includes raising false claims that the Convention is a panacea for building effective transboundary cooperation in the basin. While it would be much easier if this were true, it is not. In this respect, supporters of the Convention can be instrumental in raising awareness and understanding about the instrument. We have already witnessed the tremendous influence of the World Wildlife Fund, Green Cross International, and other partners in the Convention coming into force. This campaign should be continued with a view to expand the membership in the Convention, as well as highlight the benefits of its good-faith implementation, as a means for achieving a water-secure world for all. 


\section{Dr Kishor Uprety ${ }^{5}$ on a South Asian perspective on the UNWC}

\subsection{Hydro-geopolitics}

In South Asia, transboundary water-sharing agreements and arrangements tethering neighboring countries are subject to much criticism, as covering too much or too little. Dozens of hydroelectric dams, whether on the Indus, the Ganges, or the Brahmaputra Basin rivers, under preparation, planned, or projected, have been considered threats by most riparians, upper and lower alike. Industrial expansion, population growth, global warming, climate change, and underground water pumping exceeding natural recharge rates intensify criticism, especially when the water flow in international rivers declines below the usual and expected limit. With regard to dams, while upstream users cite vital developmental imperatives as grounds for such construction, downstream riparians often oppose them, citing their own socio-economic needs and current uses that are dependent on existing flows. The above typical crises caused by competing interests call for fine-tuning of transboundary regimes and importing of international norms into the continent.

South Asia is a region that has had to deal with some of the most difficult disputes over transboundary rivers (see Figure 4). Due to intra-regional power imbalances, mutual hostility, suspicion, and the absence of an endorsed universal legal regime, sharing transboundary waters and simultaneously sustaining riparian ecosystems have become increasingly complex. Yet none of the South Asian countries have joined the 1997 UNWC. India and Pakistan abstained from the vote on the Convention at the UNGA, while Afghanistan, Bhutan, and Sri Lanka were absent. Bangladesh, Maldives, and Nepal voted in favor of the Convention, but none has ratified or acceded to the instrument. As important, India had officially noted its objections during its adoption (see below), and as such, it is not surprising that it has not become a party.

\subsection{Dissatisfaction with the Convention}

The dearth of literature does not permit the formulation of a formal conclusion as to why the South Asian countries are uncomfortable with the Convention. Nevertheless, informal surveys with stakeholders suggest that it is due, essentially, to a perceived inability of the Convention to tackle all of the possible region-specific scenarios and the differing needs and demands among the countries. A number of reasons influenced by historical, political, and cultural elements come into play.

First, while some countries in South Asia may seem genuinely to favor a multi-country approach, collective multilateral attention to the problems of transboundary waters has been rare. Historically, the region has lacked a collective strategy, and bilateralism remains the focus.

Indeed, water has differing impacts on regional relations. Between India and Pakistan, as well as between Pakistan and Afghanistan, water disputes exacerbate already-strained bilateral relations. For Bangladesh and Nepal, the Indian approach to water is a primary source of distrust. Conspiracy theories and blame games prevail throughout South Asia. Afghanistan blames Pakistan (and Iran) for its water problems, while Nepal, Bangladesh, and Pakistan blame India for theirs. Within India and Pakistan, water shortages are blamed on the actions taken by upstream provinces or federal states. This blame

\footnotetext{
${ }^{5}$ Dr Uprety is a lawyer with the World Bank. He can be reached at aastha7@cox.net.
} 


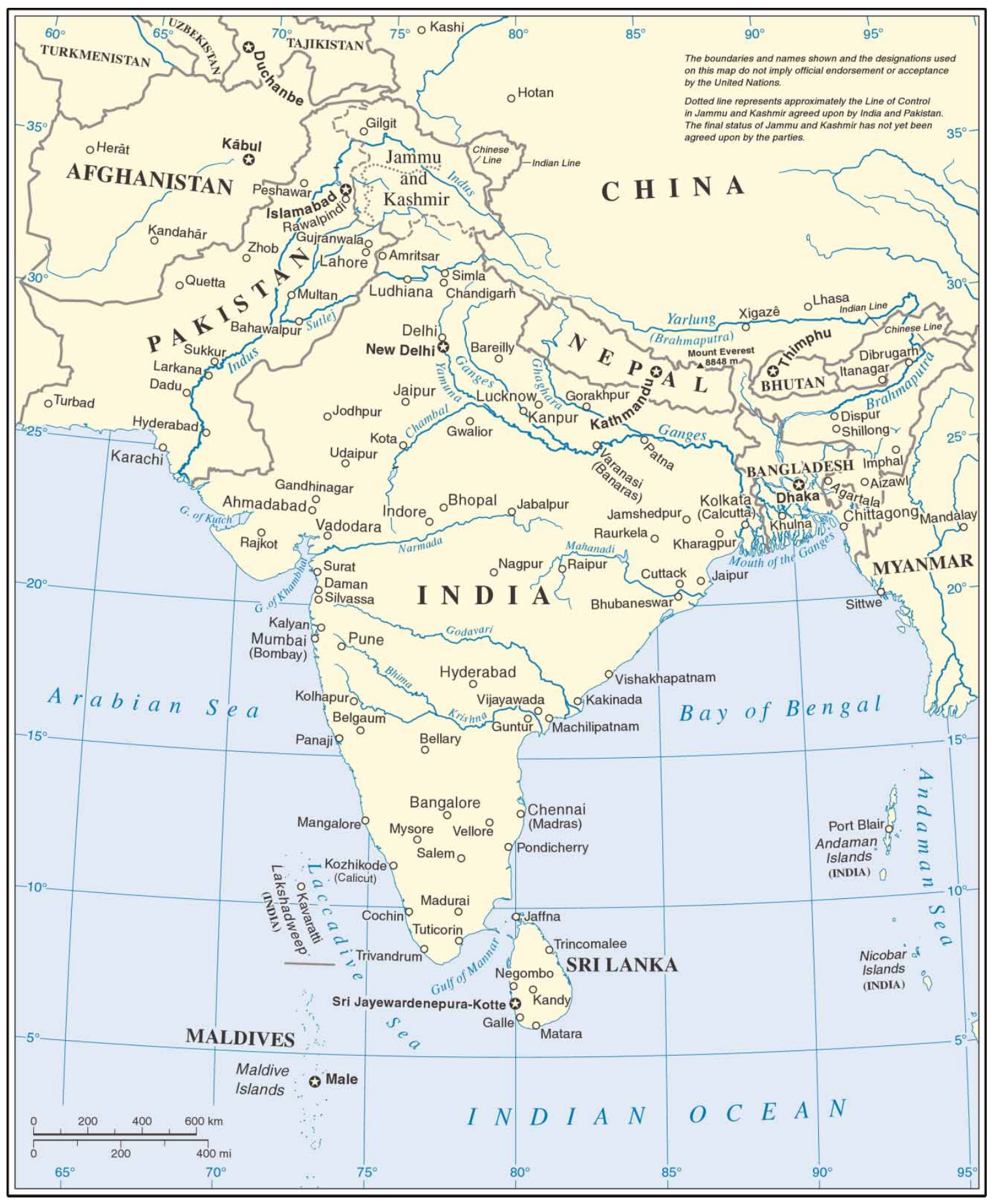

Fig. 4. Transboundary rivers of South Asia. Source: Wikipedia: http://upload.wikimedia.org/wikipedia/commons/d/d4/ South_Asia_UN.png. 
culture reflects the absence of trust that plagues intra-regional relationships, and makes multi-country river-sharing arrangements particularly difficult to materialize.

Second, these countries consider the principles of water use emanating from the Convention, though intuitively appealing, as difficult to operationalize and implement in a particularly heated geopolitical environment. Also, the many principles contained in the Convention and designed to ensure cooperation in the abstract are considered vague, if not contradictory in reality. As such, they are deemed unsuitable for resolving South Asia-specific issues where the prevailing language is centered on the idea of water as a security priority.

Indeed, there are contrasting views within the region among stakeholders and opinion-builders. There are those who rely on a realistic analysis and see water scarcity and riparian rights to water allocations as part and parcel of state security. Countries where this analysis dominates appear reluctant to engage in multilateral agreements over water, because these agreements inherently require the secession of some portion of their national sovereignty. There are also those historical materialists who endorse multilateral water-sharing cooperation, but who also believe that such cooperation can be based only on an 'unfair' allocation of water skewed toward more developed states, bigger states, or former colonial masters. Countries where this analysis dominates remain confused as to the content as well as the methodology for negotiating agreements.

Third, the treaty-making behavior in the South Asia region is unique. Due to their prevailing mutual distrust, their inability to delink hydropower from water resources, and their reservation about generalizing policy to avoid establishing precedent, the strategic approach of most of the countries is merely to theoretically engage in water-related initiatives, but practically advance only those serving their own specific interests. An interesting twist can further be noted in the case of India, which, being in a unique geographic position - upper riparian to Pakistan and Bangladesh, and lower riparian to Nepal and China - employs a differentiated strategy and, thus, considers a uniform formula for the management of water relations to be impractical.

Individual countries in the region also have their own stance on the provisions of the Convention. For instance, Pakistan considers that 'groundwater' should not be part of the definition of a 'watercourse' (Article 2), because it is difficult to determine the geographic range of aquifers that are hydraulically linked to rivers, and inequitable to include aquifers that are located entirely within the territory of one country. India takes the stance that Article 3 of the Convention, which ensures nations' rights to enter into watercourse agreements, contradicts its domestic law whereby water is constitutionally a state, rather than a Union, matter. It also claims that the term 'sustainable', as used in Articles 3 and 5 in the context of 'sustainable utilization', is not properly defined. In addition, all of the countries in the region seem to employ different interpretations of the word 'significant' in the context of 'no significant harm' (Article 7); some of the countries oppose the provision on equality of access to transboundary remedies (Article 32), which they interpret as presupposing regional integration; and Pakistan is displeased that the dispute-settlement provision (Article 33) is not binding, while India is dissatisfied that the provision contains elements for mandatory third-party procedures.

\subsection{The way forward}

Water insecurity is pervasive in the South Asia region, visible in conflicts, disputes, and tensions that have erupted within and across countries. Thus, a new approach, centered on the idea of water as a common good and a human right that is universally held and acknowledged, may need furthering. The 
Ganges basin countries are also adopting strategies for river basin management at the sub-national level. These developments, if complemented with effective persuasion of government and non-government stakeholders, may pave the way for these countries to consider a more uniform and facilitative framework on transboundary water resource management, including the UNWC. Furthermore, the conclusions emanating from the Permanent Court of Arbitration Award on the Kishenganga Dispute (2013), and from the Decision of the Neutral Expert on the Baglihar Case (2007) (both in the context of the Indus River) also could influence the understanding of these countries about the value and complementarity of treaty provisions in relation to customary international law, and encourage them to revisit their long-held positions.

\section{Dr Götz Reichert ${ }^{6}$ on entry into force of the UNWC - should Europe care?}

The upcoming entry into force of the 1997 UNWC can be attributed, in large part, to the 16 European ratifications out of the 35 that have been recorded thus far. In fact, Europe forms the largest regional group of State Parties to the UNWC. This somewhat disproportionate representation gives rise to the question: why did so many European countries join the UNWC? Moreover, given the complex, multi-level water management, allocation, and protection mechanisms already in place, what added value does an additional international framework convention have for Europe? To answer these questions, we must first consider the existing legal regime in Europe that is applied to freshwater resources.

\subsection{Specific international agreements}

Europe's hydrological environment is very diverse, ranging from water-rich areas, often under pressure from industrial pollution and frequent floods, to water-scarce regions with intensive agriculture. Moreover, Europe contains approximately 75 transboundary river basins and over 100 international agreements pertaining to internationally shared rivers, lakes, and aquifers. Following decades of mixed experiences with international cooperation, since the 1990s, a 'collective learning curve' has resulted in the emergence of a promising legal regime. Examples include the cooperative efforts between the riparians of the rivers Rhine and Danube.

Once infamous as 'Europe's most romantic sewer', the Rhine is now recovering from years of excessive industrial pollution. Ill-designed agreements from the $1970 \mathrm{~s}$, fierce disputes between upstream and downstream riparians, and the disastrous Sandoz chemical spill in 1986 finally prompted the International Commission for the Protection of the Rhine to adopt a more holistic, ecosystem-oriented approach, codified in the Convention on the Protection of the Rhine (1999). Furthermore, the fall of the Iron Curtain in 1989 opened new opportunities for international cooperation, most importantly for the Danube. The Convention on Cooperation for the Protection and Sustainable Use of the Danube River (1998) forms the legal basis for cooperation between the 14 riparian countries and the European Union (EU) within the International Commission for the Protection of the Danube River. Today, the regimes pertaining to the Rhine and Danube are exemplary for their detailed substantive regulations, clear procedural obligations, and strong institutional framework, each consisting of a conference of the parties, expert groups working on technical questions, and permanent secretariats.

\footnotetext{
${ }^{6}$ Dr Reichert is head of the Environment Department at the Centre for European Policy in Freiburg, Germany. He can be reached at goetz.reichert@t-online.de.
} 


\subsection{UNECE Watercourses Convention}

Substantive, procedural, and institutional elements are also established by the UNECE Convention on the Protection and Use of Transboundary Watercourses and International Lakes (1992) (UNECE Watercourses Convention), which functions as an overarching general agreement. Originally designed as a regional framework convention for European and Central Asian countries under the auspices of the UNECE, the UNECE Watercourses Convention was opened to all United Nations' members in February 2013. Presently, the UNECE Watercourses Convention has 40 parties.

The UNECE Watercourses Convention's institutional provisions, which establish a regular meeting of the parties and a permanent secretariat and various expert working groups, enable the regime to play an active role in the development of international water law in Europe and beyond. Together with its Protocol on Water and Health to the 1992 Convention on the Protection and Use of Transboundary Watercourses and International Lakes (1999), the Protocol on Civil Liability and Compensation for Damage Caused by the Transboundary Effects of Industrial Accidents on Transboundary Waters, to the 1992 Convention on the Protection and Use of Transboundary Watercourses and International Lakes (2003) (not yet in force), and a number of soft law instruments such as the UNECE Model Provisions on Transboundary Groundwaters (2014), the UNECE Watercourses Convention provides guidance for the continuous improvement of international cooperation on the protection and use of transboundary water resources. This is reflected in a number of subsequent international agreements, such as the 1994 Danube Convention, 2002 Meuse Agreement (International Agreement for the River Meuse 2006), the 1998 Portuguese-Spanish Basin Agreement (Convenio sobre cooperación para la protección y el aprovechamiento sostenible de las aguas de las cuencas hidrográficas hispano-portuguesas, 1998), and the 1999 Rhine Convention. All of these instruments make a serious effort to adapt the basic approach of the UNECE Watercourses Convention to their specific needs. The agreements share the catalog of aims and principles laid down by the UNECE Watercourses Convention (e.g. sustainable water management, the precautionary principle, and the polluter-pays principle). They also establish river commissions with significant tasks and competences. Most importantly, all agreements take the 'river basin' as the managerial unit for the protection and management of freshwater resources, including both surface waters and groundwater.

\subsection{EU Water Framework Directive}

The EU is also involved in international cooperation on transboundary freshwater resources in Europe, inter alia, as a party to the UNECE Watercourses Convention and conventions on the Danube, the Elbe, the Oder, and the Rhine. Since 2000, the EU Water Framework Directive 2000/60/EC (EUWFD) has played a pivotal role both in implementing the EU's obligations under international conventions and in further developing international water law. Its objective is to achieve good qualitative and quantitative status of domestic and transboundary freshwater resources in the EU by 2015. To this end, the EUWFD has set up a complex and challenging regulatory program including the phasing-out of hazardous substances, and controls over the abstraction of fresh surface water and groundwater.

The EUWFD follows the drainage basin approach and regards the hydrological 'river basin' as a starting point. The corresponding management unit is the 'river basin district' (RBD), which refers to 'the area of land and sea, made up of one or more neighboring river basins together with their associated groundwaters and coastal waters'. If transboundary effects occur within a river basin, the EU Member States concerned must establish an 'international RBD' and coordinate the implementation of the EUWFD 


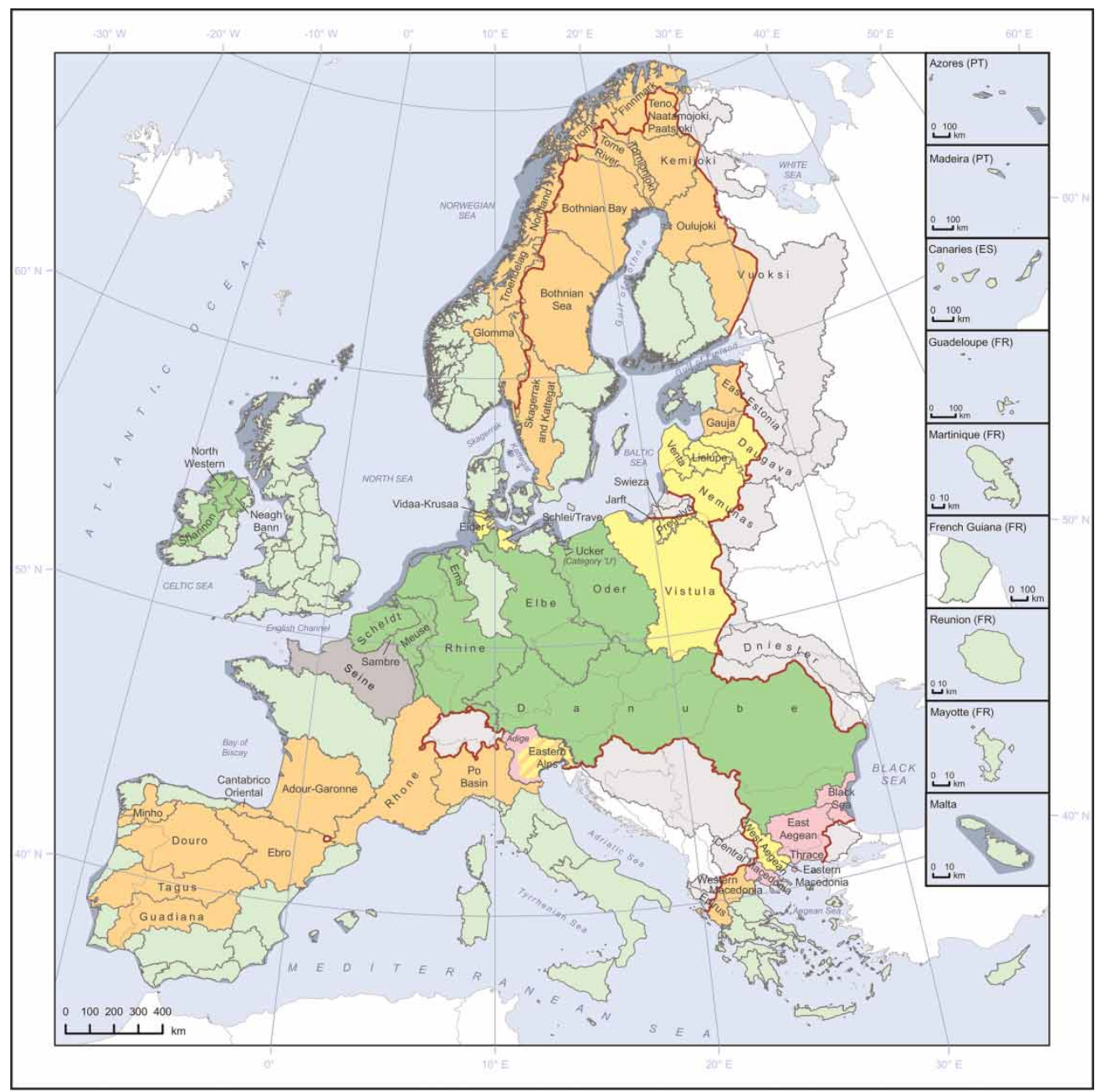

\section{EU River Basin Districts indicating transboundary co-operation}

Category 1: Co-operation agreement, co-operation body and international RBMP in place

Category 2: Co-operation agreement and co-operation body in place, but no international RBMP in place

Category 3: Co-operation agreement in place but no co-operation body or international RBMP in place

Category 2/3: Not clear whether both co-operation agreement and

co-operation body in place

Category 4: No co-operation formalised

Uncategorised

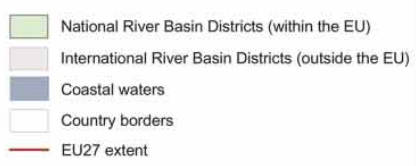

Map produced by WRc plc on behalf of the European Commission ${ }^{(}$, DG Environment, 2012
Footnotes

1) The boundaries of the National River Basin Districts are displayed using version 1.5 of the Water Information System for Europe (WISE) River Basin Districts dataset available from the European Environment Agency:

http://www.eea.europa.eu/data-and-maps/data/wise-river-basin-districts-rbds-1. This dataset is based on data reported to WISE by EU Member States, Andorra, Switzerland, Liechtenstein, Monaco and Norway.

2) The boundary of the Mayotte RBD (France) is displayed using the country borde dataset.

3) The boundaries of the International River Basin Districts are derived from the WISE River Basin Districts dataset.

4) Country border data was provided by Eurostat and is derived from EGM at a scale of
5) Coastal waters are defined in the Water Framework Directive as extending 1 nautical mile from the coastline. Some Member States included a larger part of their coastal 6) The categories allocated to each international River Basin District were established under 'Task 1b: International co-ordination mechanisms' of the EC Comparative study of pressures and measures in the major river basin management plans in the EU. Specific lact sheets for each river basin or group of river basins have been complied. Nole. nome cases a clear regarding international co-operation and/or specific forms of co-operation that would not clearly fit the description of the four categories.

7) Note that the national name of the RBD in the Greek territory of the East Aegean International RBD is Thrace, and the national name of the RBD in the Greek territory of the West Aegean International RBD is Eastern Macedonia.

Fig. 5. Map of EU river basin districts indicating transboundary cooperation. Source: European Commission: http://ec.europa. eu/environment/water/water-framework/facts_figures/pdf/Transboundary-cooperation-\%202012.pdf. 
through a single River Basin Management Plan (RBMP) (see Figure 5). A river commission established under international law may be entrusted with implementation of the EUWFD. Where an RBD extends beyond the territory of the EU, the EU Member States concerned must seek appropriate coordination with the non-EU riparians in order to achieve the EUWFD objectives. This is quite a challenge, given that $60 \%$ of the EU territory is covered by international river basins, and 55 of the current 110 RBDs are considered international. Nevertheless, international RBMPs have been adopted in several transboundary basins such as the Danube, Rhine, and Elbe within the framework of the respective international river commissions. Therefore, the EUWFD constitutes a legal interface between EU water law and international water law, thereby forming the centerpiece of an increasingly elaborate multi-level governance regime for the protection and management of transboundary freshwater resources in Europe.

\subsection{Europe and the UNWC}

In the light of this elaborate multi-level regime, why should Europe care about the entry into force of the UNWC? With the 'globalization' of the UNECE Watercourses Convention, the question becomes even more pressing. While both legal instruments are universal framework conventions open to all states, they fulfill different but complementary functions: the UNWC primarily codifies the status of customary international water law. The long-standing controversy on the relationship between the principle of equitable utilization and the 'no harm rule' clearly shows that the UNWC, at its core, is still focused on basic conflicts over transboundary freshwater resources and provides a legal framework for their balanced resolution. In contrast, the UNECE Watercourses Convention, with its detailed provisions for substantive, procedural, and institutional rules, goes well beyond the 'least common denominator' of customary law and contributes to the further development of international water law. For countries willing to pursue integrated water management based on the drainage basin approach in close cooperation with their fellow riparians, the UNECE Watercourses Convention serves as a supplement rather than an alternative to the UNWC.

Over time, European countries have learned - sometimes the hard way - that international cooperation on the protection and management of shared freshwater resources is beneficial for all riparians. This is why Europe now forms the largest block of State Parties to the UNWC. Decades of intense work in international fora, such as river commissions and expert groups, have gradually created mutual understanding and trust. The EUWFD has added challenging requirements to the substantive content of this work. On one hand, European countries should share their experiences; on the other, they can benefit from the experiences of other regions. Therefore, Europe should continue to be involved in the global discussion and further development of international water law. Becoming a party to the UNWC would be a clear commitment in this respect. In a world where water-induced controversies are still the cause of many conflicts, a 'constitution of the Earth's freshwater resources' recognized by the community of states is needed. Therefore, European countries should care, and join the UNWC.

\section{References}

Agreement (with Annexes) between the United Arab Republic and the Republic of Sudan for the full utilization of the Nile waters. Signed at Cairo, 8 November 1959; in force 22 November 1959. Available at http://internationalwaterlaw.org/ documents/regionaldocs/uar_sudan.html.

Agreement on the Nile River Basin Cooperative Framework. Available at http://internationalwaterlaw.org/documents/ regionaldocs/Nile_River_Basin_Cooperative_Framework_2010.pdf. 
Commonwealth of Independent States Agreement on Transboundary Waters (1998) Available at http://internationalwaterlaw.org/ documents/regionaldocs/1998_Commonwealth_of_Independent_States_Agreement_on_Transboundary_Waters-Russian.pdf.

Convenio sobre cooperación para la protección y el aprovechamiento sostenible de las aguas de las cuencas hidrográficas hispano-portuguesas, Albufeira, Portugal, 30 November 1998. Available at http:/faolex.fao.org/docs/texts/bi-22759.doc.

Convention on Cooperation for the Protection and Sustainable Use of the Danube River; in force 22 October 1998.

Convention on Environmental Impact Assessment in a Transboundary Context (Espoo Convention). Signed in 1991; in force 10 September 1997. Available at http://www.unece.org/env/eia/eia.html.

Convention on the Protection of the Rhine. Signed 12 April 1999. Available at http://www.iksr.org/fileadmin/user_upload/ Dokumente_en/Convention_on_the_Protection_of_the_Rhine_12.04.99-EN_01.pdf.

Decision of the Neutral Expert on the Baglihar Case (2007). Available at http://siteresources.worldbank.org/ SOUTHASIAEXT/Resources/223546-1171996340255/BagliharSummary.pdf.

Directive 2000/60/EC of the European Parliament and of the Council of 23 October 2000 establishing a framework for Community action in the field of water policy. Available at http://eur-lex.europa.eu/legal-content/EN/TXT/PDF/?uri=CELEX:02000L0060$20140101 \&$ qid $=1405346941270 \&$ from $=E N$.

Eckstein, G. (2002). Development of International Water Law and the UN Watercourse Convention. In: Hydropolitics in the Developing World: A Southern African Perspective. Turton, A. R. \& Henwood, R. (eds). African Water Issues Research Unit, Centre for International Political Studies (CIPS), University of Pretoria, South Africa, pp. 81-96. Available at http://internationalwaterlaw.org/bibliography/articles/Eckstein-Chapter-6.pdf.

Eckstein, G. \& Sindico, F. (2014) The Law of Transboundary Aquifers: many ways of going forward, but only one way of standing still. Review of European Community \& International Environmental Law 3(1), 32-42. Available at http://ssrn. com/abstract=2429569.

Exchange of notes between His Majesty's Government in the United Kingdom and the Egyptian Government in regard to the use of the waters of the River Nile for irrigation purposes. Signed 7 May 1929; in force 7 May 1929. Available at http:// internationalwaterlaw.org/documents/regionaldocs/Egypt_UK_Nile_Agreement-1929.html.

Gabčikovo-Nagymaros Project case (Hungary/Slovakia) (ICJ 1997). Available at http://www.icj-cij.org/docket/index.php? $\mathrm{p} 1=3 \& \mathrm{p} 2=3 \&$ case $=92$.

International Agreement for the River Meuse; in force 1 December 2006. Available at http://www.cipm-icbm.be/files/files/FR1.pdf.

Permanent Court of Arbitration Award on the Kishenganga Dispute (2013). Available at http://www.pca-cpa.org/showpage. asp?pag_id=1392.

Protocol on Civil Liability and Compensation for Damage Caused by the Transboundary Effects of Industrial Accidents on Transboundary Waters, to the 1992 Convention on the Protection and Use of Transboundary Watercourses and International Lakes, Kyiv, Ukraine, 21 May 2003. Available at http://www.unece.org/env/civil-liability/welcome.html.

Protocol on Water and Health to the 1992 Convention on the Protection and Use of Transboundary Watercourses and International Lakes, London, 17 June 1999. Available at http://www.unece.org/env/water/pwh_text/text_protocol.html.

Pulp Mills on the River Uruguay (Argentina v. Uruguay) (ICJ 2010). Available at http://www.icj-cij.org/docket/index.php? $\mathrm{p} 1=3 \& \mathrm{p} 2=3 \&$ code $=$ au $\&$ case $=135 \& \mathrm{k}=88$.

Treaty between the United Kingdom and Ethiopia, and between the United Kingdom, Italy, and Ethiopia, relative to the frontiers between the Sudan, Ethiopia, and Eritrea. Signed at Addis Ababa, 15 May 1902. Available at http://treaties.fco.gov.uk/ docs/pdf/1902/TS0016.pdf.

UNECE Convention on the Protection and Use of Transboundary Watercourses and International Lakes, 17 March 1992; in force 6 October 1996. Available at http://www.unece.org/env/water/text/text.html.

UNECE Model Provisions on Transboundary Groundwaters (2014). Available at http://www.unece.org/fileadmin/DAM/env/ water/publications/WAT_model_provisions/ece_mp.wat_40_eng.pdf.

UN Environmental Programme (UNEP) (2002). Atlas of International Freshwater Agreements. Available at http://www.transboundarywaters.orst.edu/publications/atlas/.

UN General Assembly Press Release GA/9248, 21 May 1997. Available at http:/www.internationalwaterlaw.org/documents/ intldocs/convention_press.html.

Ziganshina, D. (2011). The Role and Relevance of the UN Watercourses Convention to the Countries of Central Asia and Afghanistan in the Aral Sea Basin. Available at http://www.unwatercoursesconvention.org/images/2012/10/Central-AsiaAssessment.doc. 